\title{
Comparison of three diagnostic techniques for the detection of leptospires in the kidneys of wild house mice (Mus musculus) $)^{1}$
}

\author{
Carlos A. Rossetti2,5*, Bibiana N. Vanasco ${ }^{3}$, Noemí Pini ${ }^{4}$ and Julio C. Carfagnini ${ }^{5}$
}

\begin{abstract}
Rossetti C.A., Vansco B.N., Pini, N \& Carfagnini J.C. 2004. Comparison of three diagnostic techniques for the detection of leptospires in the kidneys of wild house mice. Pesquisa Veterinária Brasileira 24(1):6-10. Instituto de Patobiología, Centro Nacional de Investigaciones Agropecuarias (CNIA) del Instituto Nacional de Tecnología Agropecuaria (INTA), CC 25 (1712) Castelar, Buenos Aires, Argentina. E-mail: crossetti@ cicv.inta.gov.ar

Forty-one wild house mice (Mus musculus) were trapped in an urban area, near railways, in Santa Fe city, Argentina. Both kidneys from each mouse were removed for bacteriological and histological examination. One kidney was inoculated into Fletcher semi-solid medium and isolates were serologically typed. The other kidney was microscopically examined after hematoxylin-eosin, silver impregnation and immunohistochemical stains. Leptospires, all of them belonging to the Ballum serogroup, were isolated from $16(39 \%)$ out of 41 samples. The presence of the agent was recorded in $18(44 \%)$ and in $19(46 \%)$ out of 41 silver impregnated and immunohistochemically stained samples respectively. Additionally, leptospires were detected in high number on the apical surface of epithelial cells and in the lumen of medullary tubules and they were less frequently seen on the apical surface of epithelial cells or in the lumen of the cortical tubules, which represents an unusual finding in carrier animals. Microscopic lesions consisting of focal mononuclear interstitial nephritis, glomerular shrinkage and desquamation of tubular epithelial cells were observed in 13 of 19 infected and in 10 of 22 non-infected mice; differences in presence of lesions between infected and non-infected animals were not statistically significant $(P=0,14)$. The three techniques, culture, silver impregnation and immunohistochemistry, had a high agreement $\left(k^{3} 0.85\right)$ and no significant differences between them were detected $(P>0.05)$. In addition, an unusual location of leptospires in kidneys of carrier animals was reported, but a relationship between lesions and presence of leptospires could not be established.
\end{abstract}

INDEX TERMS: Leptospires, diagnostic techniques, Mus musculus, lesions.

RESUMO.-[Comparação de três métodos de diagnóstico para detecção de leptospiras em rins de camundongos selvagens (Mus musculus).] Foram capturados 41 camundongos (Mus musculus) na região urbana, próximo à ferrovia da cidade de

\footnotetext{
${ }^{1}$ Received on April 28, 2003.

Accepted for publication on December 8, 2003.

${ }^{2}$ Instituto de Patobiología, Centro Nacional de Investigaciones Agropecuarias (CNIA) del Instituto Nacional de Tecnología Agropecuaria (INTA), CC 25 (1712) Castelar, Buenos Aires, Argentina. *Author for correspondence. E-mail: crossetti@ cicv.inta.gov.ar

IInstituto Nacional de Enfermedades Respiratorias "E. Coni", Blas Parera 8260 (3000), Santa Fe, Argentina.

${ }^{4}$ Instituto Nacional de Enfermedades Virales Humanas "Dr. J. Maiztegui", Monteagudo 2510 (2700), Pergamino, Buenos Aires, Argentina.

${ }^{5}$ Área de Patología Básica; Facultad de Ciencias Veterinarias, UBA, Av. San Martín 5285 (1427), Buenos Aires, Argentina. *Author for correspndence. Email: crossetti@ cvm.tamu.edu
}

Santa Fé, Argentina. Os rins de cada animal capturado foram removidos para estudos bacteriológicos e histológicos. Um dos rins foi imerso em meio semi-sólido de Fletcher para isolamento de leptospiras, as quais foram serologicamente tipificadas. 0 outro rim foi microscopicamente examinado por coloração de cortes histológicos pela hematoxilina-eosina, impregnação pela prata e imunohistoquímica. Leptospiras pertencentes ao serogrupo Ballum foram isoladas em $16(39 \%)$ das 41 amostras availadas. A presença do agente foi observada em 18 (44\%) e 19 (46\%) das 41 amostras avaliadas por impregnação pela prata e imunohistoquímica, respectivamente. Leptospiras foram detectadas em grande numero na superfície apical das células epiteliais e no lumen dos túbulos medulares e foram menos frequentemente encontradas na superficie apical de células epiteliais ou no lúmen dos túbulos corticais, o que é considerado achado raro em animais portadores. Lesões microscópicas consistindo de nefrite mononu- 
clear intersticial focal, atrofia glomerular e descamação das células tubulares epiteliais foram observadas em 13 dos 19 animais infectados e em 10 dos 22 animais não infectados. Não houve diferença estatisticamente significativa entre presença de lesões em animais infectados e não infectados $(P=0,14)$. As três técnicas empregadas, isolamento, impregnação pela prata e imunohistoquímica, apresentaram alta concordância $\left(k^{3} 0,85\right)$ e não apresentaram diferenças estatisticamente significativas $(P>0,05)$. Esse trabalho descreve a presença incomum de leptospira em rins de animais portadores, porém com esse estudo não foi possível estabelecer uma relação entre lesões e presença de leptospira.

TERMOS DE INDEXACAO: Leptospira, técnicas de diagnóstico, Mus musculus, lesões.

\section{INTRODUCTION}

Rodents have been reported as chronic carriers of pathogenic serovars of leptospires (Babudieri 1958). The presence of leptospires can be detected by culture or stain of renal sections by silver impregnation or immunohistochemical techniques (Thiermann 1977, Ellis et al. 1983) and histological alterations can be observed with light microscopy by hematoxylin-eosin stain (Scanziani et al. 1989). The isolation of leptospires from kidneys of wild house mice has been reported (Brown et al. 1960, Brockie 1977, Songer et al. 1983, Vanasco et al. 2000). However, there is scarce information about detection of leptospires in kidneys of wild house mice by silver impregnation staining (Songer et al. 1983, Zamora et al. 1995) and detection by immunohistochemical staining apparently has not been reported. In addition, only a brief description of microscopic findings in kidneys of wild house mice infected by leptospires has been published (Songer et al. 1983). The purpose of this study was to evaluate the agreement among three different techniques for detection of leptospires in kidneys of wild house mice and to determine the association of leptospire detection with histopathological findings.

\section{MATERIALS AND METHODS}

Animals. Forty-one wild house mice (Mus musculus) were trapped alive in an urban area, near railways, in Santa Fe city, Argentina, using Sherman and Tomahawk traps. They were anaesthetised with ethyl ether, euthanized by cervical dislocation, and both kidneys were collected.

Bacteriological procedures. One kidney was aseptically removed, macerated and inoculated into Fletcher semi-solid medium supplemented with 5 fluorouracil $(200 \mathrm{ug} / \mathrm{ml})$ and neomycin $(300 \mathrm{ug} / \mathrm{ml})$, to inhibit the growth of contaminants. Cultures were incubated at $28^{\circ} \mathrm{C}$ and examined weekly by dark-field microscopy during 2 months. The isolates were serotyped to serogroup level by microscopic agglutination test (MAT) performed with rabbit immune sera, following the technique described by Faine (1982). Rabbit immune sera, prepared according to the standard procedures (Int. Comm. Syst. Bacteriol. 1984) and representing the following 23 leptospires serogroups, were used: Australis, Autumnalis, Ballum, Bataviae, Canicola, Celledoni, Cynopteri, Djasiman, Grippotyphosa, Hebdomadis, Icterohaemorrhagiae, Javanica, Louisiana, Mini,
Manhao, Panama, Pomona, Pyrogenes, Ranarum, Sarmin, Sejroe, Shermani and Tarassovi.

Histological methods. The other kidney was collected, macroscopically inspected, transversally sectioned in half and fixed in $10 \%$ buffered formalin for microscopic examination. After fixation and dehydration, the tissues were embedded in paraffin and $4 \mu \mathrm{m}$ thick sections were prepared. Specimens were deparaffinized, rehydrated and stained with hematoxylin-eosin (H-E) stain. In addition, samples were silver impregnated according to Warthin-Starry (W-S) method (Faine 1965) and immunohistochemically (IHC) stained, with a Streptavidin-Biotin technique, using a commercial immunoperoxidase kit (Histomouse SPÒ, Zymed Lab. Inc., Camarillo, CA). The rabbit immune sera-cocktail against 16 leptospiral serovars used as a primary antibody was provided by Dr. S. Zaki (CDC, Atlanta, USA). One kidney sample from a hamster experimentally infected with one of the strain isolated from a wild house mouse and another one from a hamster serologically negative and free from leptospire infection were used respectively as positive and negative controls for silver staining and IHC. The presence of the agent detected by WS and IHC stained, was recorded as $(+++:>60 \%$, $(++: 40$ to $60 \%$ or $(+:<40 \%$ according to the percentage of tubules filled with the agent in 10 different ( 5 cortical and 5 medullary) microscopic fields. Histopathological findings were also recorded as $(+++),(++)$ or $(+)$ according to the following parameters: $(+++)$ : $>$ of 6 inflammatory focus, $>$ of $20 \%$ of tubules with epithelial cells desquamated and $>$ of $10 \%$ of glomerular shrinkage; $(++): 4$ to 6 inflammatory focus, 10 to $20 \%$ of tubules with epithelial cells desquamated and 5 to $10 \%$ of glomerular shrinkage; and $(+):<$ of 4 inflammatory focus, < of $10 \%$ of tubules with epithelial cells desquamated and $<$ of $5 \%$ of glomerular shrinkage observed in each tissue section. Percentages of tubular epithelial cells desquamated and glomerular shrinkage were determined after counting 10 different ( 5 cortical and 5 medullary) microscopic fields. Mice were considered infected if leptospires were detected in kidneys at least by one of the three diagnostic techniques used.

Statistical analysis. The significance of association between infection and microscopic lesions was calculated using Chi square test $\left(X^{2}\right)$, performed by Statistics for Windows version 2.0 (Analytical Software, Tallahassee, Florida, USA, 1998); $P$ value of $<0,05$ was considered statistical significant. The association between isolation, silver impregnation and IHC was determined by Kappa test ( $\mathrm{k}$ ) (Landis $\&$ Koch 1977).

\section{RESULTS}

Leptospires were isolated from $16(39 \%$ samples and their presence was recorded in 18 (44\%) and in 19 (46\%) out of 41W$\mathrm{S}$ and IHC stained samples, respectively (Table 1 ). The three techniques had a high agreement $\left(k^{3} 0.85\right)$ and no significant differences between them were detected $(P>0.05)$. According to the agglutination titers, all of the isolates were assigned to the Ballum serogroup. The presence of the agent was recorded as black filiform organisms in silver impregnated (Fig. 1) and labeled of a brown color in IHC stained samples (Fig. 2).

Leptospires were observed in high number on the apical surface of epithelial cells and in the lumen of medullary tubules in all positive silver impregnated and IHC samples, and it was less frequently seen on the apical surface of epithelial cells or in the lumen of the cortical tubules and in no other place (Fig. 3). 


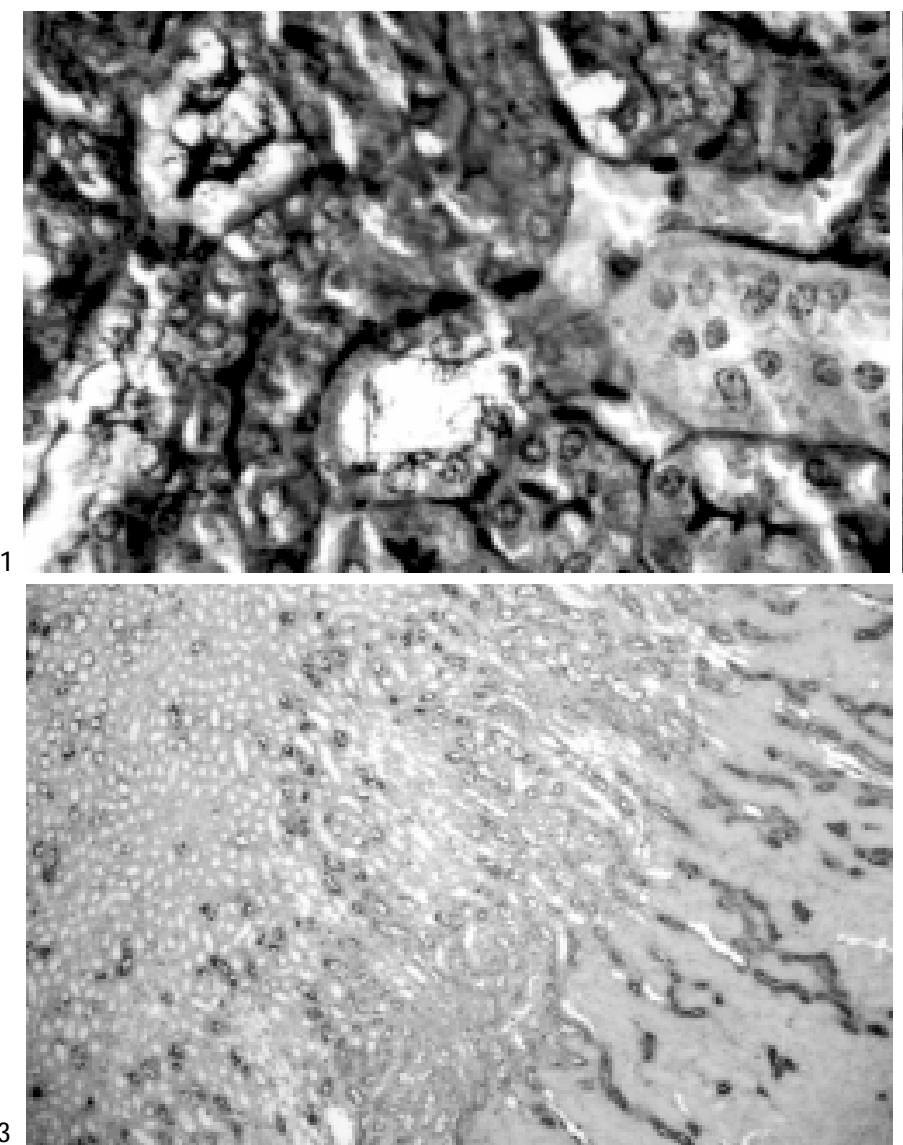

Only one of the kidneys collected (\#160) showed macroscopic alterations consisting of numerous gray-white focal depressions in the cortex no greater than $1 \mathrm{~mm}$ in

Table 1. Comparative results among the three diagnostic techniques for the detection of leptospires and the presence of microscopic lesions in kidneys of infected

mice (C: contaminated; - : negative;,,++++++ : different degree of positivism [see text for details])

\begin{tabular}{ccccc}
\hline \# Sample & Isolation & W-S & IHC & Lesions \\
\hline 111 & + & + & + & + \\
112 & + & +++ & +++ & ++ \\
113 & + & ++ & ++ & + \\
114 & + & ++ & ++ & +++ \\
115 & + & + & + & + \\
116 & + & ++ & ++ & ++ \\
117 & + & ++ & ++ & + \\
122 & + & ++ & ++ & - \\
124 & + & + & + & - \\
125 & + & +++ & +++ & - \\
157 & + & +++ & +++ & ++ \\
158 & + & ++ & ++ & ++ \\
159 & + & ++ & ++ & ++ \\
160 & + & + & + & +++ \\
200 & - & ++ & ++ & + \\
206 & + & + & + & - \\
212 & C & ++ & ++ & - \\
222 & + & + & + & + \\
244 & + & - & + & -
\end{tabular}

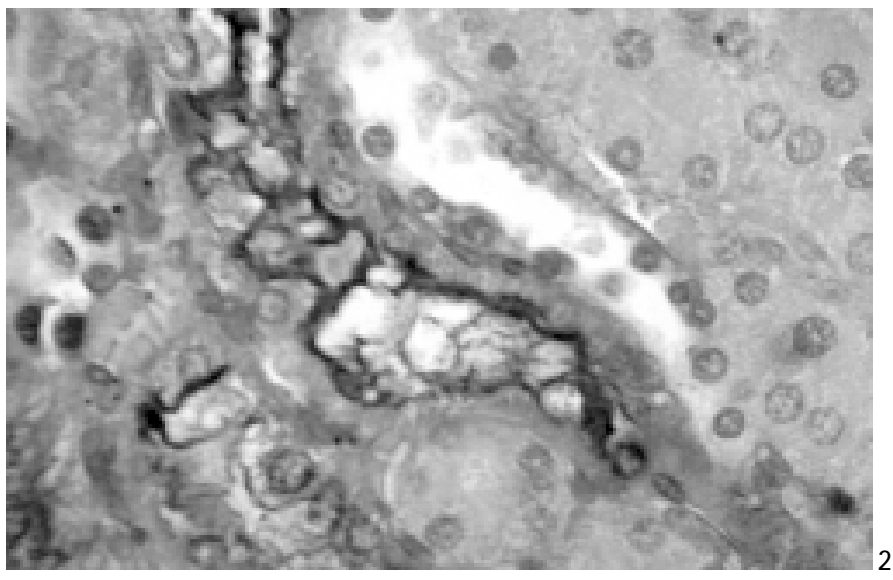

Fig. 1. Silver impregnation of a kidney of wild house mouse carrier of leptospires. The agent is black stained on the apical surface of epithelial cells and in the lumen of the renal tubules. Warthin-Starry technique.

Fig. 2. Immunohistochemical detection of leptospires on wild house mouse kidney. Leptospires are brown stained on the apical surface of epithelial cells and in the lumen of renal tubules. Note the intact epithelial cell layer in tubules infected and the absence of inflammatory reaction. Immunohistochemical stain, hematoxylin counterstain.

Fig. 3. Localization of leptospires in a kidney of wild house mice naturally infected. Leptospires are present in high number $(+++$, brown color) in medullar tubules and less frequently in cortical ones. Immunohistochemical stain, hematoxylin counterstain.

Table 2. Relationship between the degree of microscopic lesions (H/E stain) and the presence of the agent (IHC stain) observed in kidneys' section of 41 wild house mice (- negative;,,++++++ : different degree of positivism [see text for details])

\begin{tabular}{ccccc}
\hline Degree of lesions & \multicolumn{4}{c}{ Presence of the agent } \\
\cline { 2 - 5 } & - & + & ++ & +++ \\
\hline- & 12 & 3 & 2 & 1 \\
+ & 3 & 3 & 3 & - \\
++ & 3 & - & 3 & 2 \\
++ & 4 & 1 & 1 & -
\end{tabular}

diameter. Six H-E stained kidney sections were recorded as $(+++), 8$ as $(++)$ and 9 samples as $(+)$ (Table 2$)$. Lesions were observed in 13 out of 19 infected and in 10 out of 22 non-infected rodents; differences observed in the proportion of mice having kidney lesions among infected and noninfected groups were not statistically significant $(P=0.14)$. Lesions were confined to the cortex and they were similar in infected and non-infected animals. Focal interstitial infiltration of macrophages with minor proportion of lymphocytes and plasma cells, glomerular shrinkage and desquamation of tubular epithelial cells were the principal alterations observed. Tubules filled with leptospires had a normal epithelial cell layer and lesions were not associated with them. It was not possible to establish any relationship between degree of lesion and the presence of leptospires (Table 2). 


\section{DISCUSSION}

This study shows a strong agreement between leptospires isolation, W-S and IHC staining for detecting infected mice. However, there are qualitative differences among the techniques used. Isolation is the only technique employed that allows the subsequent specific identification of the agent. Moreover, silver impregnation was the least sensitive technique used, because it demonstrates the presence of spirochaetes and any spirochaeta like-artifact stained can be misidentified. Anyhow, it is accepted that if silver impregnation is done carefully, it is a highly sensitive and reliable method (Thiermann 1977). IHC has proven to be a useful marker for antigen detection in tissue samples. Employing a polyclonal rabbit serum as a primary antibody allows detecting a higher number of positive cases than using a monoclonal serum, but the identification of the agent is up to the genus level (Leptospira spp).

IHC yielded more positive results than the other methods used, but the difference with other techniques was not significant. Agreement between W-S and IHC staining in this study to detect leptospires on the epithelial cells or in the lumen of renal tubules was similar to that obtained by Scanziani et al. (1989) in pig kidneys and greater than that described by Yener and Keles (2001) in bovine kidneys. In the present study, there was only one case in which the presence of the agent was weakly detected by IHC from an infected mouse and were not observed by W-S staining. This could have been due to low number of leptospires present in the sample that were not detected by W-S stain which is considered a less sensitive diagnostic method than IHC. Hamsters were used instead of mice as positive and negative controls of WS and IHC stains because they showed higher susceptibility to infection with the strains isolated (data not shown). The lowest rate of infection was obtained by leptospiral isolation. This result was expected since leptospires are fastidious microorganisms, difficult to grow in vitro. However, the percentage of isolates reached was high, probably because samples were taken and processed immediately post-mortem. Delays in sample collection could have decreased leptospire isolation because tissue biochemical postmortem changes rapidly reduce the number of viable leptospires (Faine 1982). The association observed in this study between IHC and isolation was similar to that obtained by Ellis et al. (1983) studying naturally infected porcine kidneys. Conversely, the association between kidney silver staining and culture was greater in the present study than in those conducted by Thiermann (1977) in rats and Songer et al. (1983) in house mice.

There is general agreement that leptospires are localized on the apical surface of epithelial cells and in the lumen of proximal convoluted tubules of kidneys in carrier animals (Babudieri 1958, Miller \& Wilson 1967, Marshall 1974, Sterling \& Thiermann 1981). Sterling and Thiermann (1981) hypothesized that in this location leptospires could not only obtain nutrients from fluids to fulfill requirements for growth and replication, but also be protected from the host immune system. In the present study, leptospires were primarily seen on the apical surface of epithelial cells and in the lumen of medulla tubules, an unusual location in kidneys of carrier animals. Seibold et al. (1961) reported the presence of leptospires in the lumen of tubules of corticomedullary junction of carrier cattle with extensive inflammatory cortical reaction. The authors suggested that leptospires migrated to the corticomedullar tubules because of the damage to the cortical ones. Conversely, in the present study leptospires were seen on the epithelial cells and in the lumen of medulla tubules although generalized lesions were not observed in the cortical area.

Histological alterations registered in 13 infected and 10 noninfected kidneys were similar to those observed by Songer et al. (1983) in kidneys of wild house mice. However, the percentage of kidneys of mice carriers of leptospires with microscopic lesions in this study was higher than that reported by Songer et al. (1983) (68 vs. 57\%.

Lesions observed were consistent with those produced by leptospires in carrier animals (Sterling \& Thiermann 1981, Scanziani et al. 1989, Kener \& Yeles 2001), but according to the nature of this study, it could not be ascertained that lesions in infected kidneys were the consequence of the present infection of leptospires. Lesions in non-infected kidneys could have different origins. For instance, Songer et al. (1983) found organisms morphologically identical to Klosiella muris in kidneys of non-infected wild mice with histological lesions compatible with leptospirosis, and Babudieri (1958) theorized that lesions observed could be the consequence of previous infection by leptospires in animals recovered from the disease. Conversely, infected kidneys without histopathological lesions could be explained by the small area of each sample examined or by the absence of damage in kidneys of some carrier animals of leptospires (Babudieri 1958).

In conclusion, the three techniques evaluated showed a strong agreement for detecting wild Mus musculus carrier of leptospires. In addition, an unusual location of leptospires in kidneys of carrier animals was reported; however, a relationship between lesions and presence of leptospires could not be established.

Acknowledgements.-The authors want to thank Dr. Gabriel Sequeira, National Institute of Respiratory Diseases (INER), Santa Fe, Argentina, for helping in rodents capture; Dr. Sherif Zaki, of CDC, Atlanta, USA, for his technical assistance and Dr. Luis Calvinho, National Institute of Livestock and Agriculture Technology (INTA), Rafaela, Argentina, for reviewing of the manuscript.

\section{REFERENCES}

Babudieri B. 1958. Animal reservoirs of leptospires. Annals N.Y. Acad. Sci. 70:393-413.

Brockie R.E. 1977. Leptospiral infections of rodents in the North Island. N. Z. Vet. J. 25:89-96.

Brown R.Z. \& Gorman G.W. 1960. The occurrence of leptospiral infections in feral rodents in southwestern Georgia. Am. J. Public Health 50:682-688.

Ellis T.M., Robertson G.M., Hustas L. \& Kirby M. 1983. Detection of leptospires in tissue using an immunoperoxidase staining procedure. Aust. Vet. J. 60:364-367.

Faine S. 1965. Silver staining of spirochaetes in single tissue sections. J. Clin. Pathol. 18:381-382.

Faine S. 1982. Guideliness for the Control of Leptospirosis. WHO Offset Publication no. 67, World Health Organization, Geneva, Italy, p. 161. 
International Committee on Systematic Bacteriology, Subcommittee on the Taxonomy of Leptospira 1984. Minutes of the Meeting, August 6-10, 1982, Boston, Massachusetts, USA. Int. J. Syst. Bacteriol. 34:258-259.

Landis J.R. \& Koch, G.G. 1977. The measurement of observer agreement for categorical data. Biometrics 33:159-174.

Marshall R.B. 1974. Ultrastructural changes in renal tubules of sheep following experimental infection with Leptospira interrogans serotype pomona. J. Med. Microbiol. 7:505-508.

Miller N.G. \& Wilson R.B. 1967. Electron microscopic study of the relationship of Leptospira pomona to the renal tubules of the hamster during acute and chronic leptospiosis. Am. J. Vet. Res. 28:225-235.

Scanziani E., Siponi G. \& Mandelli G. 1989. Immunoperoxidase studies on leptospiral nephritis of swine. Vet. Pathol. 26:442-444.

Seibold H.R., Keech H. \& Bokelman D.L. 1961. Histopathologic and serologic study of subclinical leptospirosis among cattle. J. Am.Vet. Med. Assoc. 138:424-430.
Songer J.G., Chilelli C.J., Reed R.E. \& Trautman R.J. 1983. Leptospirosis in rodents from an arid environment. Am. J. Vet. Res. 44:1973-1976.

Sterling C.R. \& Thiermann A.B. 1981. Urban rats as chronic carriers of leptospirosis: An ultrastructural investigation. Vet. Pathol. 18:628-637.

Thiermann A.B. 1977. Incidence of leptospirosis in the Detroit rat population. Am. J. Trop. Med. Hyg. 26:970-974.

Vanasco B.N., Rossetti C.A., Sequeira G., Sequeira M.D., Calderón G. \& Tarabla H. 2000. First isolations of leptospires serogroup Ballum serovar arborea in Argentina. Vet. Rec. 147:245-246.

Yener Z. \& Keles H. 2001. Immunoperoxidase and histopathological examinations of leptospiral nephritis in cattle. J. Vet. Med. A 48:441447.

Zamora J., Riedemann S., Cabezas X. \& Vega S. 1995. Comparación de cuatro técnicas microscópicas para el diagnóstico de leptospirosis en roedores silvestres en el área rural de Valdivia, Chile. Revta Lat.-Am. Microbiol. $37: 267-272$. 